\title{
SPECIAL FITNESS LEVEL AND SPORTS ACHIEVEMENTS OF 15-16-YEAR-OLD POLE VAULTERS
}

\author{
Special fitness and sporting achievements of young pole vaulters
}

\author{
KAZIMIERZ KOCHANOWICZ ${ }^{1}$, MARIUSZ KLIMCZYK ${ }^{2}$ \\ ${ }^{1}$ Gdańsk University of Physical Education and Sport, Institute of Sport Theory and Human Motor Skills \\ ${ }^{2}$ Kazimierz Wielki University in Bydgoszcz, Institute of Individual Sports
}

\begin{abstract}
Mailing address: Mariusz Klimczyk, Kazimierz Wielki University in Bydgoszcz, 2 Sportowa Street, 85-091 Bydgoszcz, tel.: +48 663089733, fax: +48 52 3419160, e-mail: klimczyk1956@poczta.onet.pl
\end{abstract}

\begin{abstract}
Introduction. Control of specific performance indicators makes it possible to obtain the necessary information for determining dominant characteristics to program sports training taking into account the stage of advancement of sports and athletic performance prediction. Therefore, the aim of the study was to determine the most relevant specific performance indicators in athletes aged 15-16 years practicing the pole vault. Material and methods. The study involved 10 athletes at the first stage at the age of 15 and at the second at the age of 16 practicing pole vault, in the following clubs S.L. WKS, "Zawisza" Bydgoszcz, "Gwardia" Piła, "Śląsk” Wrocław. The study was conducted under training conditions and athletic competition in 2008-2009. The study utilized the method of pedagogical observation and case study. The research tools used involved evaluation of physical fitness and athletic fitness and sporting achievements, conducted during the competition period. To analyze the research results basic statistical methods were used. Conclusions. Special fitness growth dynamics indicators were determined, and analysis of the correlation of these indicators with the sporting achievement was performed. The highest correlation with the pole vault of 0.92 was recorded in an attempt to "fly" over the bar with rollover backwards while doing a handstand. A similar correlation of results was also shown by the special fitness analysis of three competitors with the best results in pole vault. However, in trials of running speed and muscle strength, each of the tested pole vaulters was characterized by an individual development profile.
\end{abstract}

Key words: special fitness, sport achievements, pole vault

\section{Introduction}

For many years, coaches, athletes and scientists carry out joint efforts to optimize the training process aimed at obtaining most favourable sports results. They are associated mostly with the use of modern technological capabilities, resources and training methods tailored to individual psycho-physical abilities of athletes, body treatment, and monitoring of stress reactions $[1,2,3,4]$.

Each sport has specific requirements ensuing from sporting competition that ensures the best results in the international arena.

Pole vault is one of the most spectacular athletic competitions characterized by the complex structure of movement. A particular difficulty lies in the obtaining of appropriate running speed to transfer appropriate kinematic energy to the pole and use it to move the body upwards on the deformable and flexible pole, in order to fly over the bar as high as possible.

These requirements may be met by athletes with exceptional abilities in the field of time and space orientation, differentiation of movement parameters, rhythmicity, responsiveness, stability, body balance, precision of movement, proper motoric and mental preparation [5, 6, 7].

Control of these predispositions makes it possible to obtain the necessary information for determining dominant characteristics to program sports training taking into account the stage of advancement of sports and athletic performance prediction $[8,9,10,11]$.
Most authors [12, 13, 14, 15] believe that increasing of sporting performance requires special measures, developing motoric skills and bodily functions in a certain direction necessary for the sporting discipline.

The aim of this study was to determine the most relevant special fitness indicators in athletes at the age of 15-16 years practicing the pole vault.

\section{Material and methods}

The study involved 10 athletes at the first stage at the age of 15 and at the second at the age of 16 practicing pole vault, in the following clubs S.L. WKS, "Zawisza" Bydgoszcz, "Gwardia" Piła, "Śląsk" Wrocław. The tests were held twice, at the beginning and at the end of the 2008-2009 training year. The fists tests were held in October 2008, and the second one was held in May 2009.

The athletes attended training sessions in their clubs 4 to 5 a week. One training session was approximately 90 minutes long. At school they had 3-4 hours of physical education per week, with emphasis on developing general fitness.

In the course of the research, the method of pedagogical observation and case study were used.

The studies included: assessment of physical fitness and sporting achievements, conducted during the competition period.

In order to determine fitness tests we used a system of con- 
trol indicators appropriate to the sporting discipline - i.e. pole vault [16]:

1. running speed over a distance of $30 \mathrm{~m}$ with high start (s),

2. running speed over a distance of $15 \mathrm{~m}$ with 20 metre run-up (s),

3. running speed over a distance of $15 \mathrm{~m}$ with 20 metre run-up with pole (s),

4. running speed over a distance of $15 \mathrm{~m}$ with 20 metre run-up with "putting" the pole (s) and individual $5 \mathrm{~m}$ sections of the run (points $5,6,7$ ),

5. $0-5 \mathrm{~m}(\mathrm{~s})$,

6. $5-10 \mathrm{~m}(\mathrm{~s})$,

7. $10-15 \mathrm{~m}(\mathrm{~s})$,

8. strength - measured by long jump from base $(\mathrm{cm})$,

9. explosive strength - measured by long jump $20 \mathrm{~m}$ run-up (cm),

10. shoulder girdle muscle and arm strength - as measured rope climb-3 m (s),

11. shoulder girdle muscle and arm strength, pull-ups (number of pull-ups),

12. muscle strength of back and shoulder girdle - measured by lifting the foot up to a hanging bar - training machine,

13. muscle strength of back and shoulder girdle - measured by lifting the foot up to a bar while overhang with straight arms $5 x$ the time (s),

14. shoulder girdle muscle and arm strength, pull-ups 5xwith time measured (s),

15. coordination and explosive strength measured by "flying" over the bar with rollover backwards while doing a handstand (from mattress) $(\mathrm{cm})$,

16. strength - measured by throwing a $4 \mathrm{~kg}$ ball back over one's head $(\mathrm{m})$

17. pole vault test $(\mathrm{cm})$.

Before the trials the subjects were informed in detail as to how the trials were to be held, and directly prior to the trials the trainer conducted a fifteen minute warm-up.

A detailed analysis of athletic performance was based on a report of the official competition. The accumulated research material was thoroughly analyzed using statistic methods, taking into account the minimum, maximum values, mean and standard deviation of the parameters studied, the percentage difference in the results of 15 and 16-year-old athletes, comparison of the results of individual physical fitness tests at the beginning and at the end of the annual training cycle was performed using the t-Student test for dependent samples. Differences with a significance of $\mathrm{p} \leqslant 0.05$ were considered statistically significant. Person correlation coefficients were calculated.

\section{Results}

When analyzing the results of the special fitness of 15-16 years pole vaulters within an annual training cycle one can see an improvement in all control indicators (Tab. 1). The second stage of the study also showed reduced differentiation in special fitness results. In the 15 metre run of 15-year-old athletes the best score of $3.8 \mathrm{sec}$, and the lowest $4.49 \mathrm{sec}$, with an average value of $4.24 \mathrm{sec}$ and a standard deviation of $0.23 \mathrm{sec}$. After a year of training the best result was improved by 0.06 seconds and the lowest by $0.18 \mathrm{sec}$ (from 4.49 to $4.31 \mathrm{sec}$ ). On average in 30 run the pole vaulters improved by 0.17 seconds.

In the $15 \mathrm{~m}$ run without a pole, with a pole and with "putting" the pole, the standard deviation among 15-year-olds was at 0.8-0.11 sec, and in the case of the 16-year-olds it was 0.7-0.9 sec. This indicates a lower dispersion of the results.
The biggest improvement between the first and second stage of the study was made in the run with "putting" the pole, it was $7.34 \%$. The distance divided into three - five meter sections also showed progress of the athletes ranging from 5.33 to $7.14 \%$. It is worth noting that the running speed on the third section fell (both in the first and second trial), in which the player "puts" the pole in the box.

In the case of the long jump with run up the athletes improved their results by $16 \mathrm{~cm}(2.92 \%)$. The results show a clear diversity, which at the first stage was $113 \mathrm{~cm}$, and $88 \mathrm{~cm}$ at the second stage.

In the $3 \mathrm{~m}$ rope climb attempt progress of results of $9.22 \%$ was seen. Despite the improvement in both the worst and the best results, one should emphasize their considerable dispersion. The best pole vaulter climbed the rope in 3.31 seconds, and the worst one in $8.02 \mathrm{sec}$. The results of the other strength tests evaluated based on the number pull-ups and the time taken to do 5 pull-ups were similar. At the first stage of the study the minimum number of pull-ups was 6 , and in the second it was seven. The maximum value obtained in the both stages was 17 pull-ups. In the five pull-ups trial, the group of pole vaulters improved their performance by $0.5 \mathrm{sec}(6.97 \%)$ on average.

The greatest degree of change between the first and second stage of the research (14.84\%) was in the lifting of legs up to a bar. This trial shows significant variation of results. One of the athletes only once could properly raise his feet to the bar with the group average being about 3.5 and the best result being 7 repetitions.

The results of five fold lifting of feet to the bar as quickly as possible (comparing the two stages) did not show high percentage changes (1.19\%). Despite this the average improvement in group of 0.25 seconds should be regarded as satisfactory. It can be clearly seen in the case of the athletes with inferior results performance (e.g. the weakest competitor improved his result by 1.35 seconds).

In the attempt to "fly" over the bar with rollover backwards while doing a handstand, due to the specific requirements for the proper motoric preparation and technical skills, a small progress of the results was noticed - i.e. $2.42 \%$. At both stages of research, there was a clear dispersion of the results. This is well demonstrated by the standard deviation of 20.98-22.05 cm, and the result of the spread between the minimum $(35 \mathrm{~cm})$ and maximum $(95 \mathrm{~cm}$ in the first stage and $90 \mathrm{~cm}$ in the second stage of the study).

The greatest dispersion of results was noticed in the case of pole vault. At the first stage of the study standard deviation was $42.44 \mathrm{~cm}$ and $37.75 \mathrm{~cm}$ at the second stage. In the case of the 15 -years-old pole vaulters the difference between the best and the worst result was $130 \mathrm{~cm}$, while in the case of the 16-yearolds it was $90 \mathrm{~cm}$. As a result of training the athletes improved their results by an average of $24 \mathrm{~cm}$ (6.98\%). The best result among the 15-years-old athletes was $410 \mathrm{~cm}$, and in the case of the 16-year-olds was $420 \mathrm{~cm}$. The worst results were respectively 280 and $330 \mathrm{~cm}$.

A significant increase in special fitness results at second stage of the study occurred in 7 of 17 controlled trials, namely, in the $15 \mathrm{~m}$ run and the $15 \mathrm{~m}$ run with the "put", and each of $5 \mathrm{~m}$ sections of the run, in the long jump from base and also in the throw of $4 \mathrm{~kg}$ ball backwards over the head (Tab. 1). 
Table 1. Results of special fitness tests of 15 and 16-year-old pole vaulters

\begin{tabular}{|c|c|c|c|c|c|c|}
\hline \multirow{2}{*}{ No. } & \multirow{2}{*}{ Fitness tests } & \multirow{2}{*}{$\begin{array}{c}\text { Statistical } \\
\text { values }\end{array}$} & \multirow{2}{*}{$\begin{array}{c}15 \text { years } \\
\text { A }\end{array}$} & \multirow{2}{*}{$\begin{array}{c}16 \text { years } \\
\text { B }\end{array}$} & \multirow{2}{*}{$\begin{array}{c}\% \\
\text { difference }\end{array}$} & $p$ \\
\hline & & & & & & $A \cdot B$ \\
\hline 1. & $\begin{array}{c}30 \text { metre } \\
\text { run }(s)\end{array}$ & $\begin{array}{c}\text { Average } \\
\text { SD } \\
\text { Min } \\
\text { Max }\end{array}$ & \begin{tabular}{c|}
4.24 \\
0.23 \\
3.8 \\
4.49 \\
\end{tabular} & $\begin{array}{l}4.07 \\
0.17 \\
3.74 \\
4.31\end{array}$ & 4.01 & 0.0881 \\
\hline 2. & $\begin{array}{l}15 \mathrm{~m} \\
\text { run }(\mathrm{s})\end{array}$ & $\begin{array}{c}\text { Average } \\
\text { SD } \\
\text { Min } \\
\text { Max }\end{array}$ & $\begin{array}{l}1.91 \\
0.08 \\
1.81 \\
2.10\end{array}$ & $\begin{array}{l}1.83 \\
0.07 \\
1.75 \\
1.98\end{array}$ & 4.19 & $0.0386^{*}$ \\
\hline 3. & $\begin{array}{c}15 \mathrm{~m} \\
\text { run with pole (s) }\end{array}$ & $\begin{array}{l}\text { Average } \\
\text { SD } \\
\text { Min } \\
\text { Max }\end{array}$ & $\begin{array}{l}1.97 \\
0.09 \\
1.85 \\
2.19\end{array}$ & $\begin{array}{l}1.92 \\
0.09 \\
1.80 \\
2.05\end{array}$ & 2.54 & 0.2488 \\
\hline 4. & $\begin{array}{l}\quad 15 \mathrm{~m} \\
\text { run with pole } \\
\text { with "put" (s) }\end{array}$ & $\begin{array}{c}\text { Average } \\
\text { SD } \\
\text { Min } \\
\text { Max }\end{array}$ & $\begin{array}{l}2.18 \\
0.11 \\
2.01 \\
2.38\end{array}$ & $\begin{array}{l}2.02 \\
0.08 \\
1.91 \\
2.18\end{array}$ & 7.34 & $0.0033^{*}$ \\
\hline 5. & $0.5 \mathrm{~m} / \mathrm{s})$ & $\begin{array}{c}\text { Average } \\
\text { SD } \\
\text { Min } \\
\text { Max }\end{array}$ & $\begin{array}{l}0.70 \\
0.03 \\
0.64 \\
0.75\end{array}$ & $\begin{array}{l}0.65 \\
0.02 \\
0.62 \\
0.69\end{array}$ & 7.14 & $0.0006^{*}$ \\
\hline 6. & $5.10 \mathrm{~m}(\mathrm{~s})$ & $\begin{array}{l}\text { Average } \\
\text { SD } \\
\text { Min } \\
\text { Max }\end{array}$ & $\begin{array}{l}0.72 \\
0.04 \\
0.67 \\
0.78\end{array}$ & $\begin{array}{l}0.06 \\
0.02 \\
0.63 \\
0.72\end{array}$ & 6.94 & $0.0023^{*}$ \\
\hline 7. & $10.15 \mathrm{~m}(\mathrm{~s})$ & $\begin{array}{c}\text { Average } \\
\text { SD } \\
\text { Min } \\
\text { Max } \\
\end{array}$ & $\begin{array}{l}0.75 \\
0.04 \\
0.70 \\
0.85 \\
\end{array}$ & $\begin{array}{l}0.71 \\
0.03 \\
0.66 \\
0.77 \\
\end{array}$ & 5.33 & $0.0184^{*}$ \\
\hline 8. & $\begin{array}{l}\text { long jump } \\
\text { from base } \\
(\mathrm{cm})\end{array}$ & $\begin{array}{c}\text { Average } \\
\text { SD } \\
\text { Min } \\
\text { Max }\end{array}$ & $\begin{array}{c}261.00 \\
11.79 \\
241.00 \\
284.00\end{array}$ & $\begin{array}{c}270.22 \\
5.67 \\
259.00 \\
276.00\end{array}$ & 3.53 & $0.0481^{*}$ \\
\hline 9. & $\begin{array}{l}\text { long jump } \\
\text { with run up } \\
\text { (cm) }\end{array}$ & $\begin{array}{c}\text { Average } \\
\text { SD } \\
\text { Min } \\
\text { Max }\end{array}$ & $\begin{array}{c}557.60 \\
32.86 \\
496.00 \\
609.00 \\
\end{array}$ & $\begin{array}{c}573.89 \\
33.01 \\
537.00 \\
625.00 \\
\end{array}$ & 2.92 & 0.2967 \\
\hline 10. & $\begin{array}{l}\text { climbing } \\
3 \mathrm{~m} \\
\text { rope (s) }\end{array}$ & $\begin{array}{c}\text { Average } \\
\text { SD } \\
\text { Min } \\
\text { Max } \\
\end{array}$ & $\begin{array}{l}6.83 \\
1.69 \\
4.37 \\
9.27 \\
\end{array}$ & $\begin{array}{l}6.20 \\
1.50 \\
3.31 \\
8.02 \\
\end{array}$ & 9.22 & 0.3997 \\
\hline 11. & $\begin{array}{l}\text { pull ups } \\
\text { (number) }\end{array}$ & $\begin{array}{l}\text { Average } \\
\text { SD } \\
\text { Min } \\
\text { Max }\end{array}$ & $\begin{array}{c}10.70 \\
4.06 \\
6.00 \\
17.00\end{array}$ & $\begin{array}{c}11.44 \\
3.17 \\
7.00 \\
17.00\end{array}$ & 6.92 & 0.6640 \\
\hline 12. & $\begin{array}{c}\text { raising feet to the bar, } \\
\text { training machine } \\
\text { (number) }\end{array}$ & $\begin{array}{c}\text { Average } \\
\text { SD } \\
\text { Min } \\
\text { Max } \\
\end{array}$ & $\begin{array}{l}3.10 \\
1.91 \\
1.00 \\
7.00 \\
\end{array}$ & $\begin{array}{l}3.56 \\
1.59 \\
1.00 \\
6.00 \\
\end{array}$ & 14.84 & 0.5822 \\
\hline 13. & $\begin{array}{c}\text { raising feet to the bar, } \\
5 \mathrm{x} \text { with } \\
\text { time measured } \\
(\mathrm{s})\end{array}$ & $\begin{array}{c}\text { Average } \\
\text { SD } \\
\text { Min } \\
\text { Max }\end{array}$ & $\begin{array}{l}6.71 \\
1.05 \\
5.62 \\
8.86\end{array}$ & $\begin{array}{l}6.63 \\
0.70 \\
5.66 \\
7.51\end{array}$ & 1.19 & 0.8535 \\
\hline 14. & $\begin{array}{c}\text { pull ups } \\
5 \mathrm{x} \text { with } \\
\text { time measured } \\
(\mathrm{s})\end{array}$ & $\begin{array}{l}\text { Average } \\
\text { SD } \\
\text { Min } \\
\text { Max }\end{array}$ & $\begin{array}{l}7.17 \\
1.04 \\
6.03 \\
8.69\end{array}$ & $\begin{array}{l}6.67 \\
0.90 \\
5.02 \\
7.54\end{array}$ & 6.97 & 0.2792 \\
\hline 15. & $\begin{array}{c}\text { "fly" over bar with } \\
\text { rollover backwards } \\
\text { while doing handstand } \\
\text { on mattress (cm) }\end{array}$ & $\begin{array}{c}\text { Average } \\
\text { SD } \\
\text { Min } \\
\text { Max }\end{array}$ & $\begin{array}{l}57.50 \\
20.98 \\
35.00 \\
95.00\end{array}$ & $\begin{array}{l}58.89 \\
22.05 \\
35.00 \\
90.00\end{array}$ & 2.42 & 0.8898 \\
\hline 16. & $\begin{array}{l}\text { throwing } 4 \mathrm{~kg} \text { ball } \\
\text { backwards } \\
\text { over head }(\mathrm{m})\end{array}$ & $\begin{array}{c}\text { Average } \\
\text { SD } \\
\text { Min } \\
\text { Max }\end{array}$ & $\begin{array}{c}12.75 \\
0.69 \\
11.32 \\
13.86 \\
\end{array}$ & $\begin{array}{c}14.04 \\
1.12 \\
12.89 \\
16.25 \\
\end{array}$ & 10.12 & $0.0070^{*}$ \\
\hline 17. & $\begin{array}{l}\text { pole vault } \\
\text { result }(\mathrm{cm})\end{array}$ & $\begin{array}{l}\text { Average } \\
\text { SD } \\
\text { Min } \\
\text { Max }\end{array}$ & $\begin{array}{l}347.00 \\
42.44 \\
280.00 \\
410.00\end{array}$ & $\begin{array}{c}371.22 \\
37.75 \\
330.00 \\
420.00\end{array}$ & 6.98 & 0.2082 \\
\hline
\end{tabular}

The correlation analysis performed between the performance indicators and a special fitness results of pole vaulters (significance level $\mathrm{p}<0.05$ ) reveals some characteristics that result from the training program and level of sport (Tab. 2). Noteworthy is a very high degree of correlation with the sporting result (0.98) "fly" over the bar with rollover backwards while doing a handstand. This relationship probably stems from the fact that the above exercise, like pole vault requires coordination of technical skills and motoric skills and spatial orientation in time.

High correlations with the sporting result - i.e. 0.53-0.73 were observed in the attempt of 5 fold raising of feet to the bar and the 5 pull-ups as fast as possible, throwing $4 \mathrm{~kg}$ ball backward over one's head (0.68) 30 metre run (-0.64), and climbing.

Table 2. Results of correlation analysis of physical fitness results of 16-years-old athletes with highest level of significance with the sporting result in pole vault

\begin{tabular}{|c|l|c|}
\hline No. & \multicolumn{1}{|c|}{ Physical fitness test } & Pole vault result \\
\hline 1. & 30 metre run (s) & -0.64 \\
\hline 2. & climbing 3 m rope (s) & -0.53 \\
\hline 3. & lifting of feet to bar training machine (number) & 0.60 \\
\hline 4. & lifting of feet to bar 5 x with time measured (s) & $-\mathbf{0 . 7 3}$ \\
\hline 5. & pull-ups 5 x with time measured (s) & $-\mathbf{0 . 7 0}$ \\
\hline 6. & "fly" over the bar with rollover backwards & $\mathbf{0 . 9 8}$ \\
\hline 7. & $4 \mathrm{~kg}$ ball throw over head (m) & $\mathbf{0 . 6 8}$ \\
\hline
\end{tabular}

The lack of significant correlation between the sporting results, and the $15 \mathrm{~m}$ run without a pole, run with "put" pole, running three 5-meter sections and long jump from base and long jump with run up, prompted us to further analyze the three athletes who achieved best results in pole vault (Tab. 3).

The B.M. competitor who had a result of $420 \mathrm{~cm}$ in pole vault was the best among his peers also in the "fly" over the bar with rollover backwards $(90 \mathrm{~cm})$, the pull ups with time measured ( $5.96 \mathrm{sec}$ ), the number of pull ups (13 times), $3 \mathrm{~m}$ rope climbing ( $5.03 \mathrm{sec}), 15 \mathrm{~m}$ run without pole (1.78 seconds) and with pole $(1.80 \mathrm{sec})$ and the $5 \mathrm{~m}$ distance $(0.62 \mathrm{sec})$. In the other trials his scores were below the mean value of the group.

The W.P. competitor, who had a result of $410 \mathrm{~cm}$ in pole vault, was third best in the "fly" over the bar with rollover backwards $-80 \mathrm{~cm}$, which was $21 \mathrm{~cm}$ above the group's average. He was also $32 \mathrm{~cm}$ better than the average group result in the $4 \mathrm{~kg}$ ball throws over head. In the run trials and in the remaining strength and speed tests his results were below the group's average.

The A.K. competitor, similarly as the W.P. one has his pole vault result of $410 \mathrm{~cm}$, and was second in the "fly" over the bar with rollover backwards $-85 \mathrm{~cm}$. His results were above the group's average in the $15 \mathrm{~m}$ run without pole (1.82 seconds) and with a pole (1.87 seconds). His results in the running contests $0-5 \mathrm{~m}$ (0.66 seconds), 5-10 m (0.65 seconds), 10-15 m ( 0.71 seconds) were close to the group's average. In the other fitness trials his results were below the group's average. 
Table 3. Results of special fitness tests of three 16-year-old athletes with best pole vault results

\begin{tabular}{|c|c|c|c|c|c|c|}
\hline \multirow{2}{*}{ No. } & \multirow{2}{*}{ Fitness test } & \multirow{2}{*}{$\begin{array}{c}\text { Age } \\
\text { (years) }\end{array}$} & \multirow{2}{*}{$\begin{array}{c}\text { Average } \\
\text { group } \\
\text { results }\end{array}$} & \multicolumn{3}{|c|}{ Tested competitors } \\
\hline & & & & W.P. & B.M. & A.K. \\
\hline \multirow[t]{2}{*}{1.} & \multirow[t]{2}{*}{30 metre run (s) } & 15 & 4.24 & 4.46 & 4.25 & 4.36 \\
\hline & & 16 & 4.07 & 4.31 & 4.15 & 4.21 \\
\hline \multirow[t]{2}{*}{2.} & \multirow[t]{2}{*}{$15 \mathrm{~m}$ run $(\mathrm{s})$} & 15 & 1.91 & 2.1 & 1.81 & 1.92 \\
\hline & & 16 & 1.82 & 1.98 & 1.78 & 1.82 \\
\hline \multirow[t]{2}{*}{3.} & \multirow{2}{*}{$\begin{array}{l}15 \mathrm{~m} \text { run with pole } \\
\text { (s) }\end{array}$} & 15 & 1.97 & 2.19 & 1.85 & 1.96 \\
\hline & & 16 & 1.92 & 2.05 & 1.8 & 1.87 \\
\hline \multirow[t]{2}{*}{4.} & \multirow{2}{*}{$\begin{array}{l}15 \text { m run with pole } \\
\text { with "put" (s) }\end{array}$} & 15 & 2.18 & 2.24 & 2.31 & 2.19 \\
\hline & & 16 & 2.02 & 2.18 & 2.05 & 2.02 \\
\hline \multirow[t]{2}{*}{5.} & \multirow[t]{2}{*}{$0.5 \mathrm{~m}(\mathrm{~s})$} & 15 & 0.7 & 0.73 & 0.75 & 0.71 \\
\hline & & 16 & 0.65 & 0.69 & 0.62 & 0.66 \\
\hline \multirow[t]{2}{*}{6.} & \multirow[t]{2}{*}{$5.10 \mathrm{~m}(\mathrm{~s})$} & 15 & 0.72 & 0.74 & 0.72 & 0.7 \\
\hline & & 16 & 0.67 & 0.72 & 0.68 & 0.65 \\
\hline \multirow[t]{2}{*}{7.} & \multirow[t]{2}{*}{$10-15 \mathrm{~m}(\mathrm{~s})$} & 15 & 0.75 & 0.77 & 0.8 & 0.78 \\
\hline & & 16 & 0.71 & 0.77 & 0.71 & 0.71 \\
\hline \multirow[t]{2}{*}{8.} & \multirow{2}{*}{$\begin{array}{c}\text { long jump } \\
\text { from base (cm) }\end{array}$} & 15 & 261 & 241 & 258 & 261 \\
\hline & & 16 & 270 & 268 & 259 & 271 \\
\hline \multirow[t]{2}{*}{9.} & \multirow{2}{*}{$\begin{array}{c}\text { long jump } \\
\text { with run up (cm) }\end{array}$} & 15 & 557 & 496 & 537 & 531 \\
\hline & & 16 & 573 & 537 & 541 & 567 \\
\hline \multirow[t]{2}{*}{10.} & \multirow{2}{*}{$\begin{array}{c}\text { climbing } 3 \mathrm{~m} \text { rope } \\
\text { (s) }\end{array}$} & 15 & 6.83 & 9.27 & 7.73 & 8.42 \\
\hline & & 16 & 6.2 & 8.02 & 5.03 & 7.13 \\
\hline \multirow[t]{2}{*}{11.} & \multirow{2}{*}{$\begin{array}{l}\text { pull ups } \\
\text { (number) }\end{array}$} & 15 & 10.7 & 6 & 11 & 9 \\
\hline & & 16 & 11.4 & 7 & 13 & 10 \\
\hline \multirow[t]{2}{*}{12.} & raising feet to the bar & 15 & 3.1 & 2 & 1 & 3 \\
\hline & (number) & 16 & 3.5 & 3 & 2 & 3 \\
\hline 13. & raising feet to the bar & 15 & 6.7 & 7.68 & 7.43 & 7.04 \\
\hline & $(\mathrm{s})$ & 16 & 6.6 & 7.06 & 6.32 & 7.03 \\
\hline 14. & $\begin{array}{c}\text { pull ups } \\
5 \times \text { with time measured }\end{array}$ & 15 & 7.17 & 8.69 & 8.18 & 7.79 \\
\hline & (s) & 16 & 6.67 & 7.47 & 5.96 & 7.38 \\
\hline 15. & $\begin{array}{l}\text { "fly" over bar with rollover } \\
\text { backwards while doing }\end{array}$ & 15 & 57.5 & 70 & 55 & 55 \\
\hline & handstand on mattress (cm) & 16 & 58.89 & 80 & 90 & 85 \\
\hline 16. & throwing $4 \mathrm{~kg}$ ball backwards & 15 & 12.75 & 13.29 & 12.95 & 13.86 \\
\hline & & 16 & 14.04 & 14.36 & 13.39 & 12.93 \\
\hline 17. & pole vault & 15 & 347 & 370 & 410 & 380 \\
\hline & & 16 & 371 & 410 & 420 & 410 \\
\hline
\end{tabular}

$\mathrm{p}$ - significance level; ${ }^{*} \mathrm{p} \leqslant 0.05$

\section{Discussion}

Model studies concerning the control of the training process include convincing knowledge of advisability of different approaches in the selection of indicators to assess the control of psychophysical predispositions of athletes in individual sports at different levels.

Experts $[6,7,10,12,17]$ emphasize the fact that the assessment of motoric functions of the players often involves simple motoric tests, which provide insufficient information, and they justify the need for a comprehensive approach to not only identify potential motoric skills, but psychological or functional predispositions of players.

Researchers $[13,15,18]$ indicate that further increasing of sporting level requires special measures and developing training methods in the direction necessary for the discipline and competition functions, motoric abilities and motoric skills.

Comparing the results of 15-16-year-old athletes to the previously presented results of 11-14-year-old pole vaulters [19], one can see greater dynamics in the evolving of achievements among younger athletes. For example, in an attempt to climb a 3 m rope the improvement in results among the 11-14year-olds was at $43-49 \%$, while in the case of the 15-16-yearolds it was $9.22 \%$. In the pull up trials the result improvement among the younger pole vaulters was $27-29 \%$ and in the case of the older ones it was just $7 \%$. Also similar were the dynamics of results improvements in the long jump from base and the $15 \mathrm{~m}$ run with pole, with $20 \mathrm{~m}$ run up, with $11-15 \%$ change in the case of the young pole vaulters and about $3 \%$ change in the case of the older pole vaulters. It is worth noting that in the case of the 11-14-year-olds and the 15-16-year-olds the rate of improvement in the $30 \mathrm{~m}$ run, $15 \mathrm{~m}$ run without pole and run with "put" and over the sections of 0-5 m, 5-10 m, 10-15 m was similar-i.e. 4-7\%.

The dynamics of athletic performance improvement in pole vault are very interesting. In the case of 12-14-year-old athletes at every stage of the study a systematic improvement could be seen - i.e. $20 \mathrm{~cm}$ increase in mean values with little variation in the group (SD 2.5-4.78 cm). The best result was obtained by a 14-year-old who achieved result of $285 \mathrm{~cm}$ with the group's average being $250 \mathrm{~cm}$. In the case of the 15-16-years-old pole vaulters the best result was at the level of $410-420 \mathrm{~cm}$ with the group's average of $347-371 \mathrm{~cm}$.

\section{Conclusions}

- Analysis of special fitness skills over one year training cycles (of 15-16-years-old pole vaulters) showed improvement in all controlled indicators.

- At the second stage of the study small diversity of special skills results were noticed.

- A very high degree of correlation of strength and speed results with the sporting results was found. The greatest correlation was found in the case of the "fly" over the bar with rollover backwards while doing a handstand (0.98).

- The competitor obtained the best score in pole vault (BM), also was the best among his peers in the "fly" over the bar with rollover backwards while doing a handstand and in pull ups with time measured, the number of pull ups, climbing $3 \mathrm{~m}$ rope, $15 \mathrm{~m}$ run with and without pole. The other two athletes were the $2^{\text {nd }}$ and the $3^{\text {rd }}$ in the "fly" over the bar, while in the subsequent trials they were above as well as below the mean value of the group.

Analysis of the results showed that the best indicators of 15-16-years-old pole vaulters included:

- "fly" over the bar with rollover backwards while doing a handstand, 
- 5 x pull up with time measured and raising feet to the bar on - a training machine,

- 5 x raising feet to the bar, with time measured,

- throwing a $4 \mathrm{~kg}$ ball over head,

- 30 metre run,

- climbing 3 m rope.

The analysis of the special fitness of pole vaulters in relation to their results obtained in competition reinforces the belief that information about strength, speed and coordination abilities in relation to the time and space orientation as well as technical skills of players will not only help the coach to develop an optimal sports training process providing for individual capabilities of the athletes, but also to program sporting results.

\section{Literature}

1. Sozański, H., Siewierski M. \& Adamczyk J. (2010). Individualization of training, specifics of individual training. Rocznik Naukowy AWFiS Gdańsk 20, 5-23. [in Polish]

2. Kochanowicz, K. (2006). Fundamentals of Sports Process Control Training in Gymnastics. Gdańsk: AWFiS Gdańsk. [in Polish]

3. Burke, L. (2007). Practical Sports Nutrition. Champaign: Human Kinetics.

4. Kurtz, T. (1991). How to Plan and Control Training for Peak Performance. Island Pond: Stadion.

5. Hirtz, P. (1994). Coordinative Functions. Training Study. Berlin: Sportverlag. [in German]

6. Starosta, W. (2003). Motoric Coordination Skills. Warszawa: MSMP, Instytut Sportu. [in Polish]

7. Płatonow, W.N. (1997). General Theory of Athletes Preparation in Olympic Sport. Kijew: Olimpijskaja Literatura. [in Russian]

8. Raczek, J., Mynarski W. \& Ljach W. (2003). Development and diagnosis of coordination motoric skills. Katowice: Wydawnictwo AWF Katowice. [in Polish]

9. Sawczyn, S., Kochanowicz K., Kruczkowski D. \& Dancewicz T. (1997). Prognostic features in the construction of a somatic selection for gymnastics. Trening 3, 19-24. [in Polish]
10. Sozański, H. (2002). Control as a factor in targeting and customization of training. Rocznik Naukowy AWF Gdańsk 11, 21-45. [in Polish]

11. Ważny, Z. (1997). Directions and methods of research to improve management of sport training process. Wychowanie Fizyczne i Sport 1-2, 185-206. [in Polish]

12. Ważny, Z. (1999). Methodological problems of accuracy assessment of training loads for sporting achievement. Sport Wyczynowy 7-8, 9-19. [in Polish]

13. Czerwiński, J. (1996). The dependence on the range of sports as a result of the measures of training. Trening 2, 123-131. [in Polish]

14. Sawczyn, S. (2000). Training Load in Sports Gymnastics over Long Periods of Preparation. Gdańsk: AWF Gdańsk. [in Polish]

15. Zaporożanow, W. (1988). Control in Sports Training. Kijów: Zdarowije. [in Russian]

16. Klimczyk, M. (2009). Special fitness and a sport result in 19 -year-old pole vault jumpers. Medical and Biological Sciences 23(3), 61-67.

17. Bułgakowa, N.Ż. (1986). Recruitment and Preparation of Young Swimmers. Moskwa: Fis. [in Russian]

18. Morawski, J.M. (2000). Selected issues of methodology in sports training control. In The International Scientificmethodical Conference Program - "Training at the turn of the century" Spała 27-29 November, 2000. Warszawa: AWF Warszawa. [in Polish]

19. Klimczyk, M. (2008). Managing and Monitoring of Sport Training of Pole Vaulters at Preparatory and Introductory Stages. Bydgoszcz: Wydawnictwo Uniwersytetu Kazimierza Wielkiego. [in Polish]

Submitted: October 24, 2011

Accepted: December 5, 2011 